\title{
Teaching-learning tendencies and strategies used in the leadership development of nurses
}

Tendências e estratégias de ensino-aprendizagem utilizadas no desenvolvimento da liderança do enfermeiro Tendencias y estrategias de enseñanza-aprendizaje utilizadas en el desarrollo del liderazgo del enfermero

\author{
Cristiano Caveião', Aida Maris Peres', Ivete Palmira Sanson Zagonel", \\ Simone Coelho Amestoy'", Marineli Joaquim Meier' \\ ' Universidade Federal do Paraná. Curitiba, Paraná, Brazil. \\ "Faculdades Pequeno Príncipe. Curitiba, Paraná, Brazil. \\ I"' Universidade Federal da Bahia. Salvador, Bahia, Brazil.
}

How to cite this article:

Caveião C, Peres AM, Zagonel IPS, Amestoy SC, Meier MJ. Teaching-learning tendencies and strategies used in the leadership development of nurses. Rev Bras Enferm [Internet]. 2018;71(Suppl 4):1531-9. [Thematic Issue:

Education and teaching in Nursing] DOI: http://dx.doi.org/10.1590/0034-7167-2017-0455

Submission: 06-15-2017

Approval: 11-25-2017

\begin{abstract}
Objective: To identify the tendencies and teaching-learning strategies used for leadership development in the discipline Nursing Administration in higher education institutions in Brazil. Method: Non-experimental, type survey, descriptive and exploratory, cross-sectional, with quantitative approach. Results: The dialogued lecture strategy was cited as used by 241 (91\%) professors, followed by research, by 237 (89\%), and discussion or group work, by 221 (83\%). Strategies not used were: spiral learning, 166 $(63 \%)$, and online programs, $151(57 \%)$ professors. The strategy that presents higher tendency of use is that of online courses, $104(39 \%)$. Conclusion: among the strategies mentioned, all are aligned with the directions given in the literature for nursing education, but these strategies and methodologies influence the formation of leader nurses differently.

Descriptors: Strategies; Leadership; Nursing Professor Practice; Research in Nursing Administration; Teaching.
\end{abstract}

\section{RESUMO}

Objetivo: identificar as tendências e estratégias de ensino-aprendizagem utilizadas para o desenvolvimento da liderança na disciplina de Administração em Enfermagem em instituições de ensino superior no Brasil. Método: não experimental, do tipo survey, descritivo e exploratório, de corte transversal, com abordagem quantitativa. Resultados: a estratégia de aula expositiva dialogada foi citada por 241 (91\%) docentes, seguida de pesquisa, por 237 (89\%), e de discussão ou trabalho em grupo, por $221(83 \%)$. Estratégias referidas como não utilizadas foram: aprendizagem em espiral, 166 (636\%), e programas on-line, por 151 (57\%) docentes. A estratégia que apresenta maior tendência para utilização é a de cursos on-line, 104 (39\%). Conclusão: entre as estratégias citadas, todas estão alinhadas com as indicações da literatura para o ensino de enfermagem, mas destaca-se o fato de as estratégias e metodologias influenciarem na formação de enfermeiros líderes.

Descritores: Estratégias; Liderança; Prática do Docente de Enfermagem; Pesquisa em Administração de Enfermagem; Ensino.

\section{RESUMEN}

Objetivo: identificar las tendencias y estrategias de enseñanza-aprendizaje utilizadas para el desarrollo del liderazgo en la disciplina de Administración en Enfermería en instituciones de enseñanza superior en Brasil. Método: no experimental, del tipo survey, descriptivo y exploratorio, de corte transversal, con abordaje cuantitativo. Resultados: la estrategia de aula expositiva dialogada fue citada por 241 (91\%) docentes, seguida de investigación, por 237 (89\%), y de discusión o trabajo en grupo, por 221 (83\%). Las estrategias mencionadas como no utilizadas fueron: aprendizaje en espiral, 166 $(636 \%)$, y programas online, por 151 (57\%) docentes. La que presenta mayor tendencia a la utilización es la de cursos 
online, $104(39 \%)$. Conclusión: entre las estrategias citadas, todas están alineadas con las indicaciones de la literatura para la enseñanza de enfermería, pero se destaca el hecho de que las estrategias y metodologías influencian en la formación de enfermeros líderes.

Descriptores: Estrategias; Liderazgo; Práctica del Docente de Enfermería; Investigación en Administración de Enfermería; Enseñanza.

\section{CORRESPONDING AUTHOR Cristiano Caveião E-mail: cristiano_caveiao@hotmail.com}

\section{INTRODUCTION}

Teaching-learning strategies used in the leadership development of nurses with active methodologies are considered a didactic resource of utmost relevance. Their use can encourage student autonomy, arouse curiosity, and stimulate collective and individual decision-making, since students participate and commit themselves to their learning. They are based on the development of learning through use of real or simulated experiments, seeking to solve challenges based on real practice pi-2). $^{(1)}$.

In a study on teaching-learning strategies employed in nursing for developing critical thinking in a national and international scenario, the following are described: simulation, problem-based learning $(\mathrm{PBL})$, case study, evidence-based practice (EBP), group work, practice-based learning, research, group discussion, video, dramatization, among others ${ }^{(3)}$. These strategies are considered active methodologies that seek to incorporate tendencies that are driving forces of transformation ${ }^{(4)}$.

In Brazil, the teaching strategies described as active methodologies that stimulate critical thinking in the education of leadership-related content in the discipline of Nursing Administration were: group dynamics, case study, laboratory simulation, dramatization, movies, integrative panel, creative games, group work, portfolio, online programs (Wesites, WebCT), pedagogical workshop, verbalization and observation group (VG-OG), seminars, e-learning platform, teaching with research, and strategic planning ${ }^{(3-9)}$.

Certain studies mention that professors do recognize the need for modification in their pedagogical practice; however, due to the lack of training, of interest and/or resources, the active methodology of the professor may itself suffer adaptations, which can lead to dubious results ${ }^{(1,4,10-12)}$. For a professor of Nursing Administration, a changing pedagogical practice, keeping an updated and dynamic knowledge foundation on teaching strategies focused on the development of an attitude of intellectual autonomy of students are of utmost importance, especially regarding leadership-related content.

In addition to the changes in teaching Nursing Administration, with regard to leadership development, there is a need for higher education institutions (HEIs) to integrate with health services in order to promote proper formation based on the experience of reality. This is justified because there is a certain gap between education and the demands of the work world, revealing gaps in nurses' formation ${ }^{(12-13)}$.

Given the changes that occurred in the teaching-learning of Nursing Administration and the adoption of active methodologies, it is necessary to meet national-level strategies that professors use for leadership development in this discipline.

\section{OBJECTIVE}

To identify the tendencies and teaching-learning strategies used for leadership development in the discipline of Nursing Administration in HEls in Brazil.

\section{METHOD}

\section{Ethical aspects}

The recommendations of the "Guidelines and Standards Regulating Researches Involving Human Beings" were followed, as presented in Resolution 466/2012(14). This study was approved by the Research Ethics Committee of a Brazilian university. During the study, participants were guaranteed the possibility to withdraw from participating in the research without any problems.

\section{Design, study site, and period}

Non-experimental study, type survey, descriptive and exploratory, cross-sectional, performed with professors of public and private HEls from all regions of Brazil, in the period of May to June 2016.

\section{Population or sample: inclusion and exclusion criteria}

The population of the research was of nonprobability, type census, obtained by predefined inclusion criteria and the snowball technique. For the survey of the study participants, the website of the Diretório dos Grupos de Pesquisas (DGP) of CNPq was accessed and the following terms were used: "gerenciamento", "gerência", "administração" and "gestão", with the following fields selected: Name of the line of research, Major field as Health Sciences, Field as Nursing (predominantly of the group), and only the ones with situation ticked as "certified". Afterwards, it was sent an email inviting researchers to participate in the study, which in turn indicated other participants through the use of the snowball technique.

The initial population identified in the DGP of CNPq was 777 professors; 34 who had already participated in the validation process and the pilot test were excluded. Therefore, 743 professors were invited, and from these, through snowball technique, 440 participants were indicated, 126 excluded due to repetition, resulting in 314 , which amounted to a target population of 1,057 professors invited. 265 professors of all states of the country participated in the research, the sample error being of $5.3 \%$.

The inclusion criteria were: Professor of Nursing Administration or related, registered in the DGP of CNPq; Professor of Nursing Administration or related, indicated by Professor registered in the DGP of CNPq. The exclusion criteria were: 
Nursing professors that did not teach the discipline of Nursing Administration by the time of data collection; professors from other areas of knowledge; undergraduate program not recognized by the Ministry of Education and Culture (MEC) or being a distance education program.

\section{Study protocol}

The data collection instrument was developed by the researchers and based on a review of the literature, from which it was possible to identify 24 teaching strategies used in the discipline of Nursing Administration. These were presented in structured issues that allowed participants to answer whether they use this strategy, do not use it, or if they perceived it as being a tendency to use.

32 judges, professors, and with experience in the area of Nursing Leadership were invited for the validation of appearance and content. They were chosen at random from the list of participants of the 6th meeting of the National Network of Nursing Management, which took place in March 2016.

During the first round of evaluation, 15 judges participated, and in the second round, 12 judges. After the validation process of appearance and content, the research instrument had undergone a pre-test with 19 professors, conducted in the first two weeks of April 2016. Data collection took place in the months of May and June 2016.

\section{Analysis of the results and statistics}

For statistical analysis of data, the Statistical Package for the Social Sciences (SPSS) version 17.0, Minitab 16 and Microsoft Office Excel 2010 were used. After information collection, a worksheet with the results was generated and subsequently checked for typos. The analyses were performed by using frequency distribution, percentiles, average, median, standard deviation, coefficient of variation, confidence interval, p-value, being analyzed by means of theoretical references. A significance level of $5 \%(0.05)$ and a confidence interval of $95 \%$ were adopted. The statistical tests Chi-square and $p$-value were used.

\section{RESULTS}

Among the 265 participants, it was found a predominance of 190 (71.69) public HEl professors. The area of concentration with the largest number of participants was the South, with 99 (37.4\%), Southeast, with 75 (28.3\%), Northeast, with $42(15.8 \%)$, North, with 26 (9.8\%) and the Central-West, with 23 (8.7\%).

The most cited education strategy was the dialogued lecture, by $241(91 \%)$, followed by the research strategy, mentioned by $237(89 \%)$, discussion or group work, by 221 (83\%), case study: case-based learning, 210 (79\%), practice-based learning, 208 (78.5\%), guided reflection, 180 (68\%), dramatization, $172(65 \%)$ and problem-based learning, 170 (64\%). As for the strategies not used in the discipline, there were spiral learning, with 166 (63\%), and online programs, with 151 (57\%). The strategy with highest tendency of being used is that of online courses, 104 (39\%). It was noted that the strategy of assimilation and conceptual maps is neutral in relation to the use, non-use and tendency to use.

When comparing the types of HEI with teaching strategies, there is little statistical relationship between HEIs. It is possible to observe that the teaching-learning strategy of simulation through student-centered learning environment presents significance, in which private HEls have a tendency for their use $(67 \%)$, and public a tendency not to use $(38 \%)$. It is worth mentioning there was a prevalence of use of $16(64 \%)$ strategies in private HEls and $9(36 \%)$ in public HEls (Table 1$)$.

Table 1 - Strategies utilized in leadership teaching of the discipline of Nursing Administration in Brazil and its relation to the type of higher education institute

\begin{tabular}{|c|c|c|c|c|c|c|c|c|}
\hline \multirow{2}{*}{ Strategy } & & \multicolumn{2}{|c|}{ Private } & \multicolumn{2}{|c|}{ Public } & \multicolumn{2}{|c|}{ Total } & \multirow{2}{*}{$\begin{array}{c}p \\
\text { value }\end{array}$} \\
\hline & & $\%$ & $\mathrm{n}$ & $\%$ & $\mathrm{n}$ & $\%$ & & \\
\hline Dialogued lecture & $\begin{array}{l}\text { Uses } \\
\text { Tendency }\end{array}$ & $\begin{array}{c}69 \\
6\end{array}$ & $\begin{array}{c}92 \\
8\end{array}$ & $\begin{array}{c}172 \\
18\end{array}$ & $\begin{array}{c}91 \\
9\end{array}$ & $\begin{array}{c}241 \\
24\end{array}$ & $\begin{array}{c}91 \\
9\end{array}$ & 0.707 \\
\hline Research & $\begin{array}{c}\text { Uses } \\
\text { Does not use } \\
\text { Tendency }\end{array}$ & $\begin{array}{c}69 \\
3 \\
3\end{array}$ & $\begin{array}{c}92 \\
4 \\
4\end{array}$ & $\begin{array}{c}168 \\
9 \\
13\end{array}$ & $\begin{array}{c}88 \\
5 \\
7\end{array}$ & $\begin{array}{c}237 \\
12 \\
16\end{array}$ & $\begin{array}{c}89 \\
5 \\
6\end{array}$ & 0.650 \\
\hline Case study: case-based learning. & $\begin{array}{c}\text { Uses } \\
\text { Does not use } \\
\text { Tendency }\end{array}$ & $\begin{array}{c}61 \\
2 \\
12\end{array}$ & $\begin{array}{c}81 \\
3 \\
16\end{array}$ & $\begin{array}{c}149 \\
11 \\
30\end{array}$ & $\begin{array}{c}78 \\
6 \\
16\end{array}$ & $\begin{array}{c}210 \\
13 \\
42\end{array}$ & $\begin{array}{c}79 \\
5 \\
16\end{array}$ & 0.569 \\
\hline Discussion or group work & $\begin{array}{c}\text { Uses } \\
\text { Does not use } \\
\text { Tendency }\end{array}$ & $\begin{array}{c}64 \\
1 \\
10\end{array}$ & $\begin{array}{c}85 \\
1 \\
13\end{array}$ & $\begin{array}{c}157 \\
6 \\
27\end{array}$ & $\begin{array}{c}83 \\
3 \\
14\end{array}$ & $\begin{array}{c}221 \\
7 \\
37\end{array}$ & $\begin{array}{c}83 \\
3 \\
14\end{array}$ & 0.686 \\
\hline Guided reflection & $\begin{array}{c}\text { Uses } \\
\text { Does not use } \\
\text { Tendency }\end{array}$ & $\begin{array}{l}48 \\
13 \\
14\end{array}$ & $\begin{array}{l}64 \\
17 \\
19\end{array}$ & $\begin{array}{c}132 \\
32 \\
26\end{array}$ & $\begin{array}{l}69 \\
17 \\
14\end{array}$ & $\begin{array}{c}180 \\
45 \\
40\end{array}$ & $\begin{array}{l}68 \\
17 \\
15\end{array}$ & 0.569 \\
\hline Dramatization & $\begin{array}{c}\text { Uses } \\
\text { Does not use } \\
\text { Tendency }\end{array}$ & $\begin{array}{c}52 \\
16 \\
7\end{array}$ & $\begin{array}{c}69 \\
21 \\
9\end{array}$ & $\begin{array}{l}120 \\
43 \\
27\end{array}$ & $\begin{array}{l}63 \\
23 \\
14\end{array}$ & $\begin{array}{c}172 \\
59 \\
34\end{array}$ & $\begin{array}{l}65 \\
22 \\
13\end{array}$ & 0.508 \\
\hline
\end{tabular}




\begin{tabular}{|c|c|c|c|c|c|c|c|c|}
\hline \multirow{2}{*}{ Strategy } & & \multicolumn{2}{|c|}{ Private } & \multicolumn{2}{|c|}{ Public } & \multicolumn{2}{|c|}{ Total } & \multirow{2}{*}{$\underset{\text { value }}{p}$} \\
\hline & & $\%$ & $\mathbf{n}$ & $\%$ & $n$ & $\%$ & & \\
\hline Problem-based learning & $\begin{array}{c}\text { Uses } \\
\text { Does not use } \\
\text { Tendency }\end{array}$ & $\begin{array}{c}54 \\
4 \\
17\end{array}$ & $\begin{array}{c}72 \\
5 \\
23\end{array}$ & $\begin{array}{c}116 \\
19 \\
55\end{array}$ & $\begin{array}{l}61 \\
10 \\
29\end{array}$ & $\begin{array}{l}170 \\
23 \\
72\end{array}$ & $\begin{array}{c}64 \\
9 \\
27\end{array}$ & 0.209 \\
\hline Learning at work & $\begin{array}{c}\text { Uses } \\
\text { Does not use } \\
\text { Tendency }\end{array}$ & $\begin{array}{l}43 \\
14 \\
18\end{array}$ & $\begin{array}{l}57 \\
19 \\
24\end{array}$ & $\begin{array}{c}122 \\
24 \\
44\end{array}$ & $\begin{array}{l}64 \\
13 \\
23\end{array}$ & $\begin{array}{c}165 \\
38 \\
62\end{array}$ & $\begin{array}{l}62 \\
14 \\
23\end{array}$ & 0.408 \\
\hline Poster presentation & $\begin{array}{c}\text { Uses } \\
\text { Does not use } \\
\text { Tendency }\end{array}$ & $\begin{array}{l}52 \\
10 \\
13\end{array}$ & $\begin{array}{l}69 \\
13 \\
17\end{array}$ & $\begin{array}{c}112 \\
48 \\
30\end{array}$ & $\begin{array}{l}59 \\
25 \\
16\end{array}$ & $\begin{array}{c}164 \\
58 \\
43\end{array}$ & $\begin{array}{l}62 \\
22 \\
16\end{array}$ & 0.105 \\
\hline Portfolio & $\begin{array}{c}\text { Uses } \\
\text { Does not use } \\
\text { Tendency }\end{array}$ & $\begin{array}{l}46 \\
17 \\
12\end{array}$ & $\begin{array}{l}61 \\
23 \\
16\end{array}$ & $\begin{array}{c}117 \\
35 \\
38\end{array}$ & $\begin{array}{l}62 \\
18 \\
20\end{array}$ & $\begin{array}{c}163 \\
52 \\
50\end{array}$ & $\begin{array}{l}62 \\
20 \\
19\end{array}$ & 0.622 \\
\hline Evidence-based nursing & $\begin{array}{c}\text { Uses } \\
\text { Does not use } \\
\text { Tendency }\end{array}$ & $\begin{array}{c}52 \\
4 \\
19\end{array}$ & $\begin{array}{c}69 \\
5 \\
25\end{array}$ & $\begin{array}{c}106 \\
28 \\
56\end{array}$ & $\begin{array}{l}56 \\
15 \\
29\end{array}$ & $\begin{array}{c}158 \\
32 \\
75\end{array}$ & $\begin{array}{l}60 \\
12 \\
28\end{array}$ & 0.052 \\
\hline Lecture methods & $\begin{array}{c}\text { Uses } \\
\text { Does not use } \\
\text { Tendency }\end{array}$ & $\begin{array}{c}48 \\
18 \\
9\end{array}$ & $\begin{array}{l}64 \\
24 \\
12\end{array}$ & $\begin{array}{c}108 \\
64 \\
18\end{array}$ & $\begin{array}{c}57 \\
34 \\
9\end{array}$ & $\begin{array}{c}156 \\
82 \\
27\end{array}$ & $\begin{array}{l}59 \\
31 \\
10\end{array}$ & 0.296 \\
\hline Field journal & $\begin{array}{c}\text { Uses } \\
\text { Does not use } \\
\text { Tendency }\end{array}$ & $\begin{array}{l}37 \\
24 \\
14\end{array}$ & $\begin{array}{l}49 \\
32 \\
19\end{array}$ & $\begin{array}{c}116 \\
49 \\
25\end{array}$ & $\begin{array}{l}61 \\
26 \\
13\end{array}$ & $\begin{array}{c}153 \\
73 \\
39\end{array}$ & $\begin{array}{l}58 \\
28 \\
15\end{array}$ & 0.208 \\
\hline Forums & $\begin{array}{c}\text { Uses } \\
\text { Does not use } \\
\text { Tendency }\end{array}$ & $\begin{array}{l}38 \\
20 \\
17\end{array}$ & $\begin{array}{l}51 \\
27 \\
23\end{array}$ & $\begin{array}{c}108 \\
41 \\
41\end{array}$ & $\begin{array}{l}57 \\
22 \\
22\end{array}$ & $\begin{array}{c}146 \\
61 \\
58\end{array}$ & $\begin{array}{l}55 \\
23 \\
22\end{array}$ & 0.605 \\
\hline Simulation through student-centered learning environment & $\begin{array}{c}\text { Uses } \\
\text { Does not use } \\
\text { Tendency }\end{array}$ & $\begin{array}{c}50 \\
16 \\
9\end{array}$ & $\begin{array}{l}67 \\
21 \\
12\end{array}$ & $\begin{array}{l}82 \\
72 \\
36\end{array}$ & $\begin{array}{l}43 \\
38 \\
19\end{array}$ & $\begin{array}{c}132 \\
88 \\
45\end{array}$ & $\begin{array}{l}50 \\
33 \\
17\end{array}$ & 0.003 \\
\hline Theory-based practice & $\begin{array}{c}\text { Uses } \\
\text { Does not use } \\
\text { Tendency }\end{array}$ & $\begin{array}{l}43 \\
16 \\
16\end{array}$ & $\begin{array}{l}57 \\
21 \\
21\end{array}$ & $\begin{array}{l}85 \\
48 \\
57\end{array}$ & $\begin{array}{l}45 \\
25 \\
30\end{array}$ & $\begin{array}{c}128 \\
64 \\
73\end{array}$ & $\begin{array}{l}48 \\
24 \\
28\end{array}$ & 0.167 \\
\hline Team-based learning & $\begin{array}{c}\text { Uses } \\
\text { Does not use } \\
\text { Tendency }\end{array}$ & $\begin{array}{l}41 \\
19 \\
15\end{array}$ & $\begin{array}{l}55 \\
25 \\
20\end{array}$ & $\begin{array}{l}78 \\
59 \\
53\end{array}$ & $\begin{array}{l}41 \\
31 \\
28\end{array}$ & $\begin{array}{c}119 \\
78 \\
68\end{array}$ & $\begin{array}{l}45 \\
29 \\
26\end{array}$ & 0.127 \\
\hline Pedagogical workshop & $\begin{array}{c}\text { Uses } \\
\text { Does not use } \\
\text { Tendency }\end{array}$ & $\begin{array}{l}35 \\
25 \\
15\end{array}$ & $\begin{array}{l}47 \\
33 \\
20\end{array}$ & $\begin{array}{l}69 \\
68 \\
53\end{array}$ & $\begin{array}{l}36 \\
36 \\
28\end{array}$ & $\begin{array}{l}104 \\
93 \\
68\end{array}$ & $\begin{array}{l}39 \\
35 \\
26\end{array}$ & 0.239 \\
\hline Assimilation and concept maps & $\begin{array}{c}\text { Uses } \\
\text { Does not use } \\
\text { Tendency }\end{array}$ & $\begin{array}{l}32 \\
19 \\
24\end{array}$ & $\begin{array}{l}43 \\
25 \\
32\end{array}$ & $\begin{array}{l}57 \\
72 \\
61\end{array}$ & $\begin{array}{l}30 \\
38 \\
32\end{array}$ & $\begin{array}{l}89 \\
91 \\
85\end{array}$ & $\begin{array}{l}34 \\
34 \\
32\end{array}$ & 0.080 \\
\hline Method by active video & $\begin{array}{c}\text { Uses } \\
\text { Does not use } \\
\text { Tendency }\end{array}$ & $\begin{array}{l}21 \\
34 \\
20\end{array}$ & $\begin{array}{l}28 \\
45 \\
27\end{array}$ & $\begin{array}{l}48 \\
89 \\
53\end{array}$ & $\begin{array}{l}25 \\
47 \\
28\end{array}$ & $\begin{array}{c}69 \\
123 \\
73\end{array}$ & $\begin{array}{c}2 \\
46 \\
28\end{array}$ & 0.900 \\
\hline Thinking out loud & $\begin{array}{c}\text { Uses } \\
\text { Does not use } \\
\text { Tendency }\end{array}$ & $\begin{array}{l}20 \\
40 \\
15\end{array}$ & $\begin{array}{l}27 \\
53 \\
20\end{array}$ & $\begin{array}{c}45 \\
108 \\
37\end{array}$ & $\begin{array}{l}24 \\
57 \\
19\end{array}$ & $\begin{array}{c}65 \\
148 \\
52\end{array}$ & $\begin{array}{l}25 \\
56 \\
20\end{array}$ & 0.852 \\
\hline Online courses & $\begin{array}{c}\text { Uses } \\
\text { Does not use } \\
\text { Tendency }\end{array}$ & $\begin{array}{l}15 \\
33 \\
27\end{array}$ & $\begin{array}{l}20 \\
44 \\
36\end{array}$ & $\begin{array}{l}37 \\
76 \\
77\end{array}$ & $\begin{array}{l}19 \\
40 \\
41\end{array}$ & $\begin{array}{c}52 \\
109 \\
104\end{array}$ & $\begin{array}{l}20 \\
41 \\
39\end{array}$ & 0.780 \\
\hline Spiral learning & $\begin{array}{c}\text { Uses } \\
\text { Does not use } \\
\text { Tendency }\end{array}$ & $\begin{array}{l}10 \\
45 \\
20\end{array}$ & $\begin{array}{l}13 \\
60 \\
27\end{array}$ & $\begin{array}{c}27 \\
121 \\
42\end{array}$ & $\begin{array}{l}14 \\
64 \\
22\end{array}$ & $\begin{array}{c}37 \\
166 \\
62\end{array}$ & $\begin{array}{l}14 \\
63 \\
23\end{array}$ & 0.732 \\
\hline Online programs & $\begin{array}{c}\text { Uses } \\
\text { Does not use } \\
\text { Tendency }\end{array}$ & $\begin{array}{c}8 \\
43 \\
24\end{array}$ & $\begin{array}{l}11 \\
57 \\
32\end{array}$ & $\begin{array}{c}29 \\
108 \\
53\end{array}$ & $\begin{array}{l}15 \\
57 \\
28\end{array}$ & $\begin{array}{c}37 \\
151 \\
77\end{array}$ & $\begin{array}{l}14 \\
57 \\
29\end{array}$ & 0.569 \\
\hline
\end{tabular}




\section{DISCUSSION}

Dialogued lecture is one of the most well-known and used teaching strategies. It is based on oral exposure of the contents by the lecturer, and can count with higher or lower participation of students, depending on the proposal and educational goals. This strategy allows for the possibility of turning a mere knowledge transmission class into a class in which the student will have the opportunity to show their prior knowledge, associate it to information brought by the professor and, finally, build a relation between knowledge and experience, thus enabling the emergence of questions ${ }^{(15)}$. The preparation of the lecture becomes much easier than when compared with the use of another strategy. In situations where there is no participation of the student, and the professor does not incite him, this becomes a simple traditional methodology, not having critical thinking. It should be noted that this methodology is the most used due to being the most traditional, many times occurring in a simply expository manner.

The strategy discussion or group work allows for the development of communication and interpersonal skills, which are key for a leader's performance ${ }^{(16-17)}$. Group discussion encourages the student to exercise a few management skills such as leadership, communication, conflict resolution, among others, plus the ability to expose their opinion on a topic and defend it. This was the second most cited education strategy by professors in this research.

The case study methodology assumes that both the professor and the student contribute to teaching-learning of leadership. Although the professor is more familiar with the material of a case than students, his knowledge is not regarded as final, because the participants bring new perspectives on the issues addressed $^{(15)}$. Case studies are a bridge between theory and practice, and between the classroom and the workplace, aside from encouraging students to be responsible for their own learning ${ }^{(16,18)}$ because it is required that they search for arguments with scientific grounds for the discussion.

This form of learning stimulates critical thinking when focusing on real situations, and promotes the resolution of health needs by making learning more meaningful, providing perception of the study thematic from different perspectives. It is possible to combine theory with practice, ultimately developing skills. However, according to professors, application of case studies requires more time and effective questionings to encourage students to understand the complexity of the case and the search for answers that address the requested ${ }^{(19)}$.

The guided reflection strategy favors the integration of theory and practice, assists in understanding oneself, in self-control, and, consequently, in self-empowerment. It is used for the development of complex issues proposed by the student for better performance of leadership issues. It is recommended that be promoted a teaching-learning strategy to favor better integration between theory and practice in nursing. It can be used during the internships as a way to promote personal and professional growth $^{(20)}$, thus favoring leadership development. For learning to occur, it is necessary that the student have self-confidence, and that the process be self-conducted and not conducted by others. In addition, it is important to recognize and ponder future contexts. The student has autonomy over their knowledge ${ }^{(21)}$.

One study mentions the use of guided reflection as effective not only for teaching-learning, but also for reducing the anxiety of nursing students. With this, academic learning and progress among students increases ${ }^{(22)}$. Hence, this strategy is suggested for further use and, consequently, favoring of leadership development for the nurse.

Dramatization is also called role-playing. It is a type of simulation that consists of a teaching-learning strategy based on experience, in which people assume the role of others in order to understand a phenomenon from a perspective different from theirs. Role-playing as a teaching-learning strategy develops the following skills: therapeutic communication, ethical decisionmaking, empathy with culturally diverse patients, clinical reasoning, and problem-solving.

This strategy is considered as a valuable resource and highly effective for communication education, since it encourages involvement and increases motivation and interest of the student $^{(16)}$. It is of great value for leadership education, as this competence requires experience with practical aspects, and this methodology can be extremely advantageous, due to the ease of integrating theory and practice and providing different points of view existing in the management scenario ${ }^{(5)}$.

Problem-based learning (PBL) has been employed in nursing and is noteworthy for promoting self-learning, allowing application of the acquired knowledge in practice. It is student-centered, and the professor has the role of organizing the discussion and encouraging participation of the entire group, ensuring that everyone meets the learning objectives ${ }^{(23-24)}$. This strategy provides integration through presentation of problems that are in everyday situations of future professional life, from which they are theorized and subsequently discussed among students in mentoring sessions ${ }^{(25)}$. PBL is widely used for teaching a relatively complex problem associated with basic and clinical knowledge, so that the student can manage the process of discussion and resolution by use of positive feedback ${ }^{(16)}$.

Other strategies were cited by the majority of professors of Nursing Administration for the teaching of leadership in this research as not used, but a tendency for the use of these modalities is perceived, as is the case of online courses. The use of the internet in undergraduate disciplines favors the development of student skills in dealing with various technological tools and in pursuing continuous education through online $\operatorname{courses}^{(26)}$. These stimulate flexibility, access and cost-effectiveness in nursing education as they are considered an effective teaching strategy ${ }^{(15)}$. They also facilitate the search for knowledge by students themselves, which leads to the development of their autonomy. Online courses are becoming more accessible to students and oftentimes at no financial cost. It is worth noting that this strategy can assist in complementing leadership content that cannot be covered in the classroom, due to the course load of the discipline.

Online environments, as mentioned by professors in this study, are a tendency in leadership education. It is worth mentioning that, in this modality, it is necessary for the professor to encourage students to seek their knowledge and monitor 
their performance and access to the virtual environment in order to commit to their learning, because freedom of access can result in false feeling of ease and lack of need to comply with hours of study ${ }^{(27)}$. Innovative learning is the main way for exercising autonomy, considered as a way to understand and work positively in addition to the prevailing context. It is open, unlimited and endless, intelligent and dynamic, and allows for changes in the status quo ${ }^{(21)}$.

Students of various levels in the area of nursing describe online courses as a worthy contribution for interaction among peers, self-reflection and discipline regarding time limits for compliance with the activities ${ }^{(28)}$. It should be noted that online courses have benefits for students since they present convenience and flexibility, being able to complement the contents already learned on leadership in the nursing field. The lack of high level use of online programs for the teaching of nursing leadership draws attention in this research, since the current educational context is already immersed in a technological age. Despite its lack of use, the tendency still exists, as pointed out by the results.

Usage of these new technologies in education allows for teaching flexibility, making it more dynamic and current, permeable to requests and needs of the context in which the user is inserted. The creation of effective educational programs depends on how new technologies are employed to achieve certain objectives. It is important that its use considers pedagogical principles and is suitable for the development of educational products oriented to the virtual environment ${ }^{(29)}$. It is estimated that online programs are not used by universities for teaching-learning of leadership content due to the absence of specific programs for the development of this competence in the discipline of Nursing Administration.

Concept maps - an innovation of science education - has been used in nursing education for over 25 years ${ }^{(29)}$, with its insertion stemming from the analysis of its employment in several other fields ${ }^{(30)}$. Several authors have examined the ways in which conceptual maps functioned as a learning strategy ${ }^{(29-30)}$ and performed analyses in order to use a strategy to promote meaningful learning, a collaborative teaching-learning, higher critical thinking, clinical decision making, and a methodology to provide the connections between theory and practice ${ }^{(29)}$. Consequently, conceptual maps encourage the clarification of existing concepts for the stimulation of critical thinking ${ }^{(16,31)}$ and leadership exercise.

Several international ${ }^{(32-34)}$ and national studies s-7,10-11,16,35-36) $^{(3,10}$ have mentioned simulation as a strategy for leadership teaching in nursing, which diverges from this research, as it denotes that its use is still scarce and of low frequency. Simulation with realistic scenarios enables the exploration of situations that encourage development of managerial skills such as leadership.

Team-based learning (TBL) is a teaching strategy that initially was developed as an alternative to expositions for large groups, but during its development may also involve small-group learning strategies. The challenges that the TBL strategy enforces are: the promotion of the involvement of the teams, and motivation preservation, since its strength lies in the collective construction of knowledge (collective intelligence), in the power of teamwork, and on its potential for project construction, problem solving and formulation of questions. The strength of team learning is a result of the quality of everyone's participation ${ }^{(16,37-38)}$. The research showed that this strategy is rarely used and, perhaps, not well known by professors.

In turn, flipped classroom promotes the development of active, investigative and collaborative learning. The content and the instructions are studied online before the student attends classroom, which now becomes a place for developing the contents already studied by performing practical activities, such as problem solving and projects, group discussion and laboratories. Inversion occurs because, if the traditional classroom education serves for the professor to transmit information to the student, who, after class, must study the content transmitted and make some assessment activity to show that they assimilated it, in the flipped classroom approach, the student studies before class and the class becomes a place for active learning, where there are questions, discussions and practical activities. The professor develops on the students' difficulties, instead of presenting the content of the discipline ${ }^{(39)}$. This teaching strategy can be aligned with the use of online environments, so that the student can access the content before entering the classroom.

In research conducted with professors, technical visits were cited as valuable learning opportunities in Nursing Administration; experience in daily practice helps in learning how to perform, because students come into direct contact with the duties of nurses in managing the process of care and also health institutions ${ }^{(9)}$. The opportunity to know and verify, by means of visits, how the leadership of nurses in health organizations and the labor market contributes to review the methodological and theoretical concepts as well as express the dialogue produced in the classroom ${ }^{(40)}$.

Given the strategies and methodologies mentioned in this research, it is worth remembering that none of them have indication of being used as a main form of leadership education in nursing. Also associated with active methodologies, the use of technological resources is shown to be necessary ${ }^{(15)}$. Other resources that can be used are virtual reality, games, smartphone and software applications, among others.

In HEls where classes are many - a reality of many courses in Brazil, mainly in private institutions - the use of active methodologies implies effort and creativity of the university to overcome the adversities that overlap their governability. In some situations, there is, contrary to the text of the pedagogical project and institutional discourse, a lack of resources and support for the professors themselves to implement education based on active methodologies.

\section{Study limitations}

One limitation of this research is the number of participants, mainly concentrated in public HEls. It is assumed that there is another parcel of professors in private HEls, and who were not invited or reached through snowball technique, because the website of those institutions are not included in information such as the name of the professors by course or by discipline, and these are not linked to research groups registered at CNPq.

Contributions to the field of nursing, health or public policy

This research helped to identify the most commonly used strategies for leadership education and showed that its results could provide further research on the effectiveness of the tendencies 
in the teaching of Nursing Administration. It is recommended to perform qualitative research that enables analysis of how different strategies and methodologies may influence the formation of nurse leaders.

\section{CONCLUSION}

The most cited teaching-learning strategies for leadership development in the discipline of Nursing Administration were: dialogued lecture $(91 \%)$, research $(89 \%)$, discussion or group work $(83 \%)$, case study: case-based learning $(79 \%)$, guided reflection $(68 \%)$, dramatization $(65 \%)$ and PBL $(64 \%)$. Among the ones with tendency to use were online courses (39\%), and as unused strategies, online programs (57\%) and spiral-based learning (63\%).

On the other hand, a not very indicated strategy by the professors was simulation through student-centered learning environment (50\%). Simulation, in other areas like medicine and other nursing contents, has been expanding and acquiring space within education, which diverges from this research. It is again highlighted that the teaching-learning strategy most mentioned as tendency is the online courses. The ones that remained neutral, since the professors use, do not use or observe as a tendency for its use, were assimilation and conceptual maps (34\%). Online programs and spiral learning are not employed in the Brazilian scenario, but there is insertion of new strategies in teaching-learning such as: TBL, flipped classroom, just in time, among others.

\section{FUNDING}

Postgraduate scholarship (Demanda Social) by CAPES - Coordination of Higher Education and Graduate Training.

\section{REFERENCES}

1. Borges TS, Alencar G. Metodologias ativas na promoção da formação crítica do estudante: o uso das metodologias ativas como recurso didático na formação crítica do estudante do ensino superior. Cairu Rev [Internet]. 2014 [cited 2017 May 05];3(4):11943. Available from: http://www.cairu.br/revista/arquivos/artigos/2014_2/08\%20METODOLOGIAS \%20ATIVAS $\% 20$ NA $\% 20$ PROMOCAO $\% 20$ DA $\% 20 F O R M A C A O \% 20 C R I T I C A \% 20 D O \% 20 E S T U D A N T E . p d f$

2. Sobral FR, Campos CJG. The use of active methodology in nursing care and teaching in national productions: an integrative review. Rev Esc Enferm USP[Internet]. 2012 [cited 2017 May 05];46(1):208-18. Available from: http://www.scielo.br/pdf/reeusp/v46n1/ en_v46n1a28.pdf

3. Waterkemper R, Prado ML. Estratégias de ensino-aprendizagem em cursos de graduação em Enfermagem. Av Enferm [Internet]. 2011[cited 2017 May 05];29(2):234-46. Available from: http://www.scielo.org.co/pdf/aven/v29n2/v29n2a03.pdf

4. Caveião C, Zagonel IPS, Coelho ICM, Peres AM, Montezeli JH. Perception of teachers about the learning process in nursing administration. Cogitare Enferm[Internet]. 2015[cited 2017 May 05];20(1):103-10. Available from: http://revistas.ufpr.br/cogitare/ article/view/40628/24854

5. Spagnol CA, Monteiro LAS, Paula CL, Bastos JM, Honorato JAG. Vivenciando situações de conflito no contexto da enfermagem: o esquete como estratégia de ensino-aprendizagem. Esc Anna Nery Rev Enferm[Internet]. 2013 [cited 2017 May 05];17(1):184-89. Available from: http://www.scielo.br/pdf/ean/v17n1/26.pdf

6. Kalinowski CE, Massoquetti RMD, Peres AM, Larocca LM, Cunha ICKO, Gonçalves LS, et al. Metodologias participativas no ensino da administração em enfermagem. Interface [Internet]. 2013 [cited 2017 May 05];17(47):959-67. Available from: http://www.scielo. $\mathrm{br} / \mathrm{pdf} / \mathrm{icse} / \mathrm{v} 17 \mathrm{n} 47 / \mathrm{aop} 4413 . \mathrm{pdf}$

7. Valente JA. Blended learning e as mudanças no ensino superior: a proposta da sala de aula invertida. Educar Rev [Internet]. 2014[cited 2017 May 05];4:79-97. Available from: http://www.scielo.br/pdf/er/nspe4/0101-4358-er-esp-04-00079.pdf

8. Caveião C, Zagonel IPS, Coelho ICM, Peres AM, Montezeli JH. Skills in nursing management discipline: descriptive exploratory research. O Braz J Nurs[Internet]. 2014[cited 2017 May 05];13(4):602-12. Available from: http://www.objnursing.uff.br/index.php/ nursing/article/viewFile/4770/pdf 332

9. Caveião C, Zagonel IPS, Peres AM, Hey AP, Montezeli JH, Visentin A. Prática docente da disciplina de Administração em Enfermagem: facilidades e dificuldades. Rev Práxis [Internet]. 2015 [cited 2017 May 05];7(13):105-15. Available from: http://web.unifoa.edu. br/praxis/numeros/13/105-115.pdf

10. Carrara GLR, Rigobello JL, Luize PB, Baldo PL, Bernardes A, Gabriel CS. O ensino da liderança na graduação em enfermagem. Atas CIAQ [Internet]. 2015 [cited 2017 May 05];2:108-13. Available: http://proceedings.ciaiq.org/index.php/ciaiq2015/article/ view/225/221

11. Oliveira SN, Prado ML, Kempfer SS. Use of simulations in nursing education: an integrative review. Rev Min Enferm [Internet]. 2014[cited 2017 May 05];18(2):487-95. Available from: http://www.reme.org.br/artigo/detalhes/941

12. Wisniewski D, Papa MAF, Inoue KC, Evora YDM, Matsuda LM. The teaching of management in nursing and the needs of the market: an integrative review. Rev Enferm UFPE [Internet]. 2014 [cited 2017 May 05];8(supl-2):3747-57. Available from: http:// www.revista.ufpe.br/revistaenfermagem/index.php/revista/article/viewArticle/4918

13. Sade $P$, Peres $A$, Wolff $L$. The formation of the managerial competencies of nurses: an integrative review. Rev Enferm UFPE[Internet]. 2014[cited 2017 May 05];8(6):1739-45. Avalialable from: http://www.revista.ufpe.br/revistaenfermagem/index.php/revista/article/ 
viewArticle/4595

14. Brasil. Ministério da Saúde. Resolução n. 466, de 12 de Dezembro de 2012. Trata de pesquisas e testes em seres humanos. Diário Oficial [da] República Federativa do Brasil. Brasília, D.F., 2012.

15. Paim AS, lappe NT, Rocha DLB. Metodologias de ensino utilizadas por docentes do curso de enfermagem: enfoque na metodologia problematizadora. Enferm Glob [Internet]. 2015 [cited 2017 May 05];37(1):153-69. Available from: http://scielo.isciii.es/pdf/eg/ v14n37/pt_docencia2.pdf

16. $\mathrm{Xu} \mathrm{JH}$. Toolbox of Teaching strategies in nurse education. Chinese Nursing Research [Internet]. 2016 [cited 2017 May 05];3:54-57. Available from: http://www.sciencedirect.com/science/article/pii/S2095771816300482

17. Lucchese R, Calixto BS, Vera I, Paula NI, Veronesi CL, Fernandes CNS. Group teachingin nursing/Teaching group nursing practices guided by the Pichon-Rivière theoretical framework. Esc Anna Nery Rev Enferm [Internet]. 2015 [cited 2017 May 05];19(1):212-9. Available from: http://www.scielo.br/pdf/ean/v19n2/en_1414-8145-ean-19-02-0212.pdf

18. Freitas MIP, Carmona EV. Estudo de caso como estratégia de ensino do processo de enfermagem e do uso de linguagem padronizada. Rev Bras Enferm [Internet]. 2011[cited 2017 May 05];64(6):1157-60. Available from: http://www.scielo.br/pdf/reben/v64n6/ v64n6a25.pdf

19. Laver S, Croxon L. Narrative pedagogy with evolving case study: a transformative approach to gerontic nursing practice for undergraduate nursing students. Nurse Educ Pract [Internet]. 2015[cited 2017 May 05];15(5):341-44. Available from: https://www. ncbi.nlm.nih.gov/pubmed/25960064

20. Jootun D, Mcgarry W. Reflection in Nurse Education. J Nurs Care[Internet]. 2014[cited 2017 May 05];3(2):148-50. Available from: https://www.ncbi.nlm.nih.gov/pubmed/9515621

21. Ávila VC, Amestoy SC, Porto AR, Thofehrn MB, Trindade LL, Figueira AB. Visão dos docentes de enfermagem sobre a formação de enfermeiros-líderes. Cogitare Enferm [Internet]. 2012 [cited 2017 Sep 10];17(4):621-7. Available from: http://revistas.ufpr.br/ cogitare/article/view/30357/19635

22. Sharif E, Dehbozorgi R, Mani A, Vossoughi M, Tavakoli P. The effect of guided reflection on test anxiety in nursing students. Nurs Midwifery Stud[Internet]. 2013 [cited 2017 May 05];2(3):16-20. Available from: https://www.ncbi.nlm.nih.gov/pmc/articles/ PMC4228543/

23. Chan ZC. Nursing problem-based learning activity: song writing and singing. Nurse Educ Pract [Internet]. 2014 [cited 2017 May 05];14(4):380-4. Available from: http://www.nurseeducationinpractice.com/article/S1471-5953(14)00015-8/fulltext

24. Chan ZC. Students 'and experts' perspectives on three learning and teaching activities. Nurse Educ Pract [Internet]. 2014 [cited 2017 May 05];14(5):449-54. Available from: http://www.nurseeducationinpractice.com/article/S1471-5953(14)00037-7/pdf

25. Oliveira LL, Moura NPR, Tanajura DM. Aprendizagem baseada em problemas e o currículo tradicional na educação em enfermagem: uma revisão bibliográfica. Educationis [Internet]. 2015 [cited 2017 May 05];3(1):34-41. Available from: http://sustenere.co/journals/ index.php/educationis/article/view/SPC2318-3047.2015.001.0004

26. Leite KNS, Santos SR, Andrade SSC, Zaccara AAL, Costa TF. A Internet e sua influência no processo de ensino-aprendizagem de estudantes de enfermagem. Rev Enferm UERJ [Internet]. 2014 [cited 2017 May 05];21(4):464-70. Available from: http://www.epublicacoes.uerj.br/index.php/enfermagemuerj/article/view/10006

27. Holanda VR, Pinheiro AKB, Holanda ER, Santos MCL. Teaching and learning in a virtual environment: nursing student's attitude. Rev Min Enferm [Internet]. 2015 [cited 2017 May 05];9(1):141-7. Available from: http://www.reme.org.br/exportar-pdf/992/ en_v19n1a12.pdf

28. Olson CC, Benham-Hutchin M. Learner presence in online nursing education. OJNI [Internet]. 2014 [cited 2017 May 05];18(3). Available from: http://www.himss.org/learner-presence-online-nursing-education

29. Rodrigues RCV, Peres HHC. An educational software development proposal for nursing in neonatal cardiopulmonary resuscitation. Rev Esc Enferm USP [Internet]. 2013 [cited 2017 May 05];47(1):231-7. Available from: http://www.scielo.br/pdf/reeusp/v47n1/ en_a30v47n1.pdf

30. Daley B, Morgan S, Black S. Concept Maps in Nursing Education: a historical literature review and research directions. J Nurs Educ [Internet]. 2016[cited 2017 May 05];55(11):631-9. Available from: http://www.healio.com/doiresolver?doi = 10.3928/01484834-20161011-05

31. Kinchin I. Novakian concept mapping in university and professional education. Knowledge management \& E-learning [Internet]. 2015 [cited 2017 May 05];7(1):1-5. Available from: http://www.kmel-journal.org/ojs/index.php/online-publication/article/viewArticle/406

32. Kilgore RV, Goodwin ME, Harding RA. Adding context to a simulation module for leadership and management baccalaureate nursing students. J Nurs Educ Pract [Internet]. 2013[cited 2017 May 05];3(9):148-55. Available from: http://www.sciedu.ca/journal/ index.php/jnep/article/view/2496

33. Smith SB. Integrating simulation in a BSN leadership and management course. J Nurs Educ Pract [Internet]. 2013 [cited 2017 May 05];3(11):121-32. Available from: http://www.sciedu.ca/journal/index.php/jnep/article/view/2092

34. Curtis E, Ryan C, Roy S, Simes T, Lapkin S, O’Neil B, et al. Incorporating peer-to-peer facilitation with a mid-level fidelity student led simulation experience for undergraduate nurses. Nurse Educ Pract [Internet]. 2016[cited 2017 May 05];20:80-4. Available from: https://www.ncbi.nlm.nih.gov/pubmed/27509080 
35. Teixeira INDO, Felix JVC. Simulação como estratégia de ensino em enfermagem: revisão de literatura. Interface[Internet]. 2011[cited 2017 May 05];39:1173-83. Available from: http://www.scielo.br/pdf/icse/v15n39/aop3011.pdf

36. Costa RRO, Medeiros SM, Vitor AF, Lira ALBC, Martins JCA, Araújo MS. Tipos e finalidades da simulação no ensino de graduação em enfermagem: revisão integrativa da literatura. Rev Baiana Enferm [Internet]. 2013 [cited 2017 May 05];30(3):1-11. Available from: https://portalseer.ufba.br/index.php/enfermagem/article/view/16589

37. Cheng CY, Liou SR, Hsu TH, Pan MY, Liu HC, Chang CH. Preparing nursing students to be competent for future professional practice: applying the team-based learning-teaching strategy. J Prof Nurs [Internet]. 2014[cited 2017 May 05];30(4):347-56. Available from: https://www.ncbi.nlm.nih.gov/pubmed/25150421

38. Elliott S. Using a modified team-based learning approach to teach nursing students about communicable disease control and community health nursing. J Nurs Educ [Internet]. 2014[cited 2017 May 05];53(1):651-3. Available from: http://www.healio.com/ doiresolver?doi $=10.3928 / 01484834-20141027-01$

39. Bergmann J. Sala de aula invertida: uma metodologia ativa de aprendizagem. Rio de Janeiro: LTC, 2016.

40. Badaró CSM, Fabri ACOC, Deus RL, Dutra HS. Technical visit carried out during the formation of nursing students: a descriptive study. O Braz J Nurs [Internet]. 2016 [cited 2017 May 05];15(1):42-51. Available from: http://www.objnursing.uff.br/index.php/ nursing/article/view/5194 